Como citar este artículo en APA: Galeano Atehortúa, Adolfo. (2020). El sobrenatural histórico y la Iglesia. Cuestiones Teológicas, 47 (107), 001-021. doi: http://doi.org/10.18566/cueteo.v47n107.a01

Fecha de recepción: 06 de junio de 2019 / Fecha de aceptación: 23 de diciembre de 2019

\title{
EL SOBRENATURAL HISTÓRICO Y LA IGLESIA
}

\author{
The Historical Supernatural and the Church
}

\author{
Adolfo Galeano Atehortúa ${ }^{1}$
}

\section{Resumen}

El profundo cambio cultural que estamos experimentando por el paso de la cultura de la modernidad a la postmodernidad supone un nuevo reto a la eclesiología: el paso de una comprensión metafísica de la Iglesia a una histórico-salvífica, ya propuesta por el Concilio Vaticano II. La modernidad quiso anular el sobrenatural, y a ese desafío respondió la Nouvelle Théologie de H. de Lubac y von Balthasar. En el presente artículo me propongo presentar la eclesiología desde el punto de vista del sobrenatural histórico, muy estudiado en la exégesis por von Rad y en la teología judía por Fackenheim y A. J. Heschel. De parte católica, estudiaron el tema del sobrenatural en la historia J. Daniélou y Urs von Balthasar. Así que, en la primera parte, después de considerar la crisis cultural de la modernidad, estudio el sobrenatural histórico según la Sagrada Escritura y teniendo en cuenta las perspectivas presentadas por los autores citados. En la segunda parte, me ocupo del sobrenatural histórico como humus propio de la Iglesia, lo que le da su identidad propia pero también su resiliencia frente a los enormes cambios de la historia. Para leer el proceso de construcción de la Iglesia utilizo el parangón con la obra de la creación y la nueva hermenéutica bíblica. Así como el cosmos es la arcilla con la que el Señor está creando al hombre, pues somos polvo de las estrellas, así también la historia es la arcilla con la que el Espíritu está realizando a la Iglesia. En cuanto a la hermenéutica bíblica tengo en cuenta que la interpretación del Antiguo Testamento se mantiene en el Nuevo Testamento. Es decir, los autores neotestamentarios leyeron el A.T. como los mismos profetas habían leído las tradiciones de Israel. No intento presentar la Iglesia que se perfila en la postmodernidad sino solo el fundamento sobrenatural histórico que ella tiene, que es la segunda parte del artículo. Tampoco pretendo estudiar la eclesiología que plantean los teólogos de la ciencia, aunque trata de tener en cuenta algunas de sus ideas sobre el tema.

Palabras clave: Sobrenatural histórico; Postmodernidad; Escatología; Evolución; Universo einstenian; Eclesiología.

1 Doctor en Teología por la Universidad Gregoriana de Roma, Italia. Licenciado en Teología por la misma Universidad. Licenciado en Filosofía en la Universidad de San Buenaventura, Colombia. Actualmente es profesor de teología en la Universidad San Buenaventura, Colombia. Correo electrónico: pazybienco@une.net.co 


\section{Abstract}

The profound cultural change we are undergoing, due to the transition from modernity to postmodernity, poses a new challenge to ecclesiology: The transition from a metaphysical understanding of the Church to a salvific-historical one, already suggested by Second Vatican Council. Modernity wanted to eliminate the supernatural, but de Lubac's and von Balthasar's Nouvelle Théologie rose to that challenge. The article aims to present theology from the perspective of the historical supernatural, which was addressed by von Rad in exegesis and by Fackenheim and Heschel in Jewish theology. Within Catholicism, the issue of the supernatural in history was addressed by Daniélou and von Balthasar. Bearing this in mind, after considering the crisis of culture in modernity, the article first addresses, based on the aforementioned authors, the historical supernatural according to the Holy Scriptures. Then, it considers the historical supernatural as the humus of the Church, which provides both an identity of her own and a source of resilience to significant changes throughout history. To understand the development process of the Church, it is compared to the work of creation, considering new biblical hermeneutic. Just like cosmos is the clay that the Lord uses to create the human being, because we are all made of star stuff, so is history the one that the Spirit uses to build the Church. Regarding biblical hermeneutics, the article considers that the interpretation of the Old Testament remains within the New Testament, that is, that the writers of the latter read the first, just like the prophets read the traditions of Israel. It is not intended to present the Church that is being developed in postmodernity, but only to introduce her historical supernatural foundation. Neither it is the purpose to address the ecclesiology developed by theologians of science, though it considers some of their ideas regarding such issue.

Key words: Historical Supernatural; Postmodernity; Eschatology; Evolution; Einsteinian Universe; Ecclesiology.

\section{Introducción}

"La Iglesia puede seguir siendo siempre miserable, pobre e imperfecta: mientras siga viviendo en este mundo en sus miembros, puede estar débil y enferma: a pesar de ello, esta Iglesia será siempre el instrumento del poder divino. Más aún, precisamente por su sufrimiento es como la Iglesia realiza la salvación del mundo y da testimonio de la victoria de Cristo".

(D. Barsotti, 1967, p. 72).

La Iglesia se encuentra hoy ante una situación semejante a la que se dio cuando se hundió el imperio romano. Está en medio de una desintegración explosiva de la modernidad. Auschwitz y las dos guerras 
mundiales volvieron trizas los ideales de la modernidad: que el hombre es bueno y racional, que el progreso es real y que la fraternidad universal es humanamente realizable, que existe el progreso hacia una sociedad justa, racional y feliz. La caída de la modernidad nos ha demostrado que no somos dueños del tiempo ni del futuro. Por eso el hombre de la postmodernidad es un hombre desilusionado, ha perdido las ilusiones que le había dado la modernidad. El siglo XX podría ser visto como la era de la anti-metafísica. Una era en la que la ciencia física suplanta a la metafísica usurpando su rol y aportando una nueva visión del mundo científico. Se argumenta que ha llegado una era post-ideológica con una filosofía anti-metafísica. La ciencia de Einstein, Hubble y Hawkings, pretende ofrecer una visión comprensiva de toda la realidad. De ahí la necesidad de una eclesiología que tenga en cuenta el fenómeno socio-histórico de la desintegración de la modernidad y confronte los problemas que trae consigo la llamada posmodernidad (Ward, 2005; Ford, Muers, 2005).

La eclesiología, por lo demás, es una tarea interminable y siempre creativa, porque la Iglesia es una realidad viva y siempre en proceso. El inmenso reto de la eclesiología hoy es el cambio de paradigma que estamos experimentando: el paso de una comprensión metafísica de la Iglesia a una histórica-salvífica. La cultura técnico-científica y la globalización exigen una nueva expresión al pensamiento sobre la Iglesia para responder a los retos que a ella se le plantean. Pero también, puesto que la Iglesia se realiza en la historia, se encuentra en nuestro tiempo en una nueva etapa de esa realización que nos muestra nuevos aspectos de ella que es necesario comprender. De hecho, así se ha ido realizando la Iglesia en la historia, afrontando retos, batallando problemas y dificultades, padeciendo ataques de todo orden: "En su caminar en medio de tentaciones y tribulaciones, la Iglesia se ve confortada con el poder de la gracia de Dios, que le ha sido prometida para que no desfallezca de la fidelidad perfecta por la debilidad de la carne, antes, al contrario, persevere como esposa digna de su Señor y, bajo la acción del Espíritu Santo, no cese de renovarse hasta que por la cruz llegue a aquella luz que no conoce ocaso" ( L.G. n. 9).

Para leer el proceso de construcción de la Iglesia utilizo el parangón con la obra de la creación y la nueva hermenéutica bíblica, a la vez que tengo en cuenta el nuevo contexto cultural de la postmodernidad. El primero, la creación del cosmos, pues como dice san Clemente de Alejandría: "Así como la voluntad de Dios es un acto y se llama mundo, así también su intención es la salvación de los hombres y se llama Iglesia”. En efecto, un misterioso estallido original llamado big bang produjo el universo a partir de una bola de fuego inicial, así también se originó el nacimiento de la Iglesia a partir de la explosión creadora de Pentecostés, pues "contenida toda entera, en su primer día, en el estrecho cenáculo de Jerusalén" (Lubac, 1968, 39), estalló el misterio de la Iglesia para expandirse por toda la tierra. Así como el cosmos es la arcilla con la que el Señor está creando al hombre, pues somos polvo de las estrellas, así también la historia es la arcilla con la que el Espíritu está realizando a la Iglesia.

En cuanto a la hermenéutica bíblica tengo en cuenta que la interpretación del A. T. se mantiene en el N.T. Es decir, los autores neotestamentarios leyeron el A.T. como los mismos profetas habían leído las tradiciones de Israel. O sea, leyeron esa historia escatológicamente con la conciencia de la presencia en ella del Misterio del Sobrenatural. Para los autores del N.T., el A.T. es el libro de las esperanzas de Israel y se trata de unas esperanzas "in crescendo". La fe Yahvista de los profetas hace que a su luz los acontecimientos adquieran un sentido nuevo y un futuro nuevo. Esto mismo es lo que van a realizar los autores del N.T. con el material del A.T. El acontecimiento Jesucristo produjo una nueva lectura e interpretación de todas las tradiciones del A.T. Según G. von Rad "del nuevo acontecimiento -la predicación de Jesús, su muerte 
y su resurrección- procede una comprensión del Antiguo Testamento que difiere profundamente de la enseñanza escriturística del judaísmo, y también de la secta de Qumran. Ya no se leía el Antiguo Testamento solo bajo el aspecto de la ley, que todo lo dominaba" (von Rad, 2009, 423). Por eso el N.T. no se puede leer bajo la Weltanschauung o cosmovisión helenista sino bajo la perspectiva bíblica. La Iglesia primitiva leyó la vida de Jesús a la luz del A.T. Por ejemplo, la figura del siervo sufriente de Isaías llegó a ser una de las claves principales de interpretación del N.T. para comprender el acontecimiento Jesucristo.

Pablo recibió ese kerigma por medio de la comunidad antioquena y lo interpreta también siguiendo el método del A.T. y a la luz del acontecimiento de la Cruz y de la Resurrección. De hecho, entendió su misión a la luz del A.T., pues "el Evangelio no era algo creado de nuevo, ex nihilo, sino la culminación del plan de Dios para Israel y a través de Israel" y "la misión de Pablo como apóstol de los gentiles era la puesta en práctica de la misión de Israel para las naciones". (Dunn, 2012, 634). Es la hermenéutica de san Agustín cuando dice: "Apenas encontraréis un salmo en que no hable Cristo y la Iglesia, o Cristo solo, o la Iglesia sola”. (San Agustín, In Ps. 59, 1).

\section{El sobrenatural histórico en la Sagrada Escritura}

"El lugar en que Dios revela el secreto de su persona es la historia" (von Rad, 2009, 436).

"La teología cristiana habla de la historia escatológicamente" (Moltmann, 1974, 196).

La postmodernidad parece un ciclón que está arrasando con instituciones, ideologías, paradigmas culturales. De hecho, se habla del fin de la metafísica, de las utopías, del fin de la filosofía, de la razón, de la verdad y la ley natural entendidas por la modernidad y cimentadas en abstracto y en esencias estáticas y universales. Es el ocaso de la idolatría conceptual de la modernidad. La postmodernidad está obligando a un cambio de paradigma, o sea, pasar de aquel definido por el cosmos al de la historia, del espacial al temporal, del pasado al futuro, de lo estático a lo dinámico.

En la teología se habla del fin de la escolástica y de la eclesiología de la sociedad perfecta fundamentada en la metafísica. Al mismo tiempo se habla de la recuperación de pilares constitutivos de la teología olvidados en la modernidad: el paradigma bíblico de pensamiento, la ortopraxis, la verdad como realidad viva, práctica y no abstracta, las doctrinas, no como cárceles de la verdad, sino sometidas al desarrollo, la escatología histórica o la historia escatológica (Walls, 2010). Y algo que ha sido un aporte grandioso de la Nouvelle Théologie: la Iglesia no está construida sobre la ley natural racional sino en el sobrenatural anunciado por el kerigma evangélico.

Ahora bien, para entender el pensamiento histórico cristiano es necesario ir a sus raíces, que evidentemente están en el pensamiento bíblico. Digamos de entrada que estamos ante un concepto de historia distinto al de la modernidad. Partimos del hecho de que la historia no es autónoma o inmanente, como tampoco lo es la creación natural. Tiene, en efecto, una finalidad escatológica. La lectura inmanente 
y pretendidamente racional de la historia, como la que ha hecho la modernidad, es una lectura sesgada. Esto significa que la teología hoy debe enfrentar el secularismo de la modernidad en el campo de la historia, pues él no puede responder a los interrogantes terribles y dramáticos de la historia. Ella, como dice Fackenheim, "está llena de sufrimiento injusto". (Fackenheim, 2002, 94). Ni el secularismo ni la ciencia pueden explicar el mal, que es una realidad histórica, no cosmológica. Al dios de la razón, al dios deísta de la modernidad, lo exterminó la historia. Si ha habido alguien que haya percibido esto con toda su agudeza fue Nietzsche. Por eso habló de la muerte de dios, del ocaso de los ídolos, y quiso refugiarse aterrado en el pasado, pues para él la verdad del hombre es arcaica y se rebeló contra la actitud cristiana de negar "la felicidad en esta tierra": "Permaneced fieles a la tierra y no creáis a quienes os hablan de esperanzas supraterrenales", dijo. (Nietzsche. 1981, 69)

En la consideración de la historia distingo cuatro visiones de ella. La primera es la historia de la salvación, que como dice Lubac es un concepto que el Concilio ha restaurado con toda su fuerza y que se refiere a las "mirabilia Dei" o acciones salvadoras de Dios en la historia. Según Daniélou: "la revelación cristiana es la de una historia santa, la historia de los mirabilia Dei. La Biblia es el documento de esa historia. Y es admirable que, único entre los libros sagrados, el de los cristianos sea una historia y no una exposición de doctrinas" (Daniélou, 1953, 110). Otra distinción que hago es la historia de la Iglesia, que está dentro de la historia de la salvación pero que no la agota, puesto que Dios actúa su obra salvadora también fuera de la Iglesia. Un tercer concepto es la historia cósmica que es estudiada por la ciencia y que ciertamente hace parte también de la historia de la salvación, más aún, la eclesiología postmoderna escruta la naturaleza cósmica y evolutiva de la Iglesia, tomando conciencia de los vínculos que ella tiene con el universo en evolución. Teniendo en cuenta, además, que el entero drama de la naturaleza desplegándose durante miles de millones de años también es revelación de Dios. Sobre esta historia dice T. de Chardin: "Bajo el movimiento de la vida, se oculta, sin duda alguna, la acción continua de un Ser que empuja, desde dentro, el Universo". (Chardin, 1973, 36). Es preciso también tener en cuenta la afirmación de Pablo en Romanos: "La creación será liberada de la esclavitud de la corrupción, para entrar en la gloriosa libertad de los hijos de Dios". (Rm 8, 21) y en Efesios: "Dios nos ha dado a conocer el misterio de su voluntad, el plan que había proyectado: dar plenitud a los tiempos en Cristo y todo, lo que está en la tierra y en cielo, recapitularlo en El" (Ef 1,9-10). Y así como la historia parece un caos, así también el cosmos. Vivimos en un universo frío, hostil, agitado y violento: estrellas, meteoritos, asteroides, cometas, nebulosas, nubes de estrellas, galaxias que sufren enormes explosiones, agujeros negros, sistemas supergalácticos, y fragmentos de materia cósmica que lo cruzan. En el universo einsteniano no hay direcciones ni fronteras, no es algo rígido colocado en el espacio: es un continuo amorfo, sin arquitectura fija, plástico y variable, sujeto al cambio y a la distorsión en el que todos los sistemas gravitacionales están en movimiento incesante.

Por último, está la historia profana o secular, que es la visión de la historia o su afirmación como algo meramente inmanente. Como lo aclara Hauerwas, la historia secular es la historia que implica una comprensión del tiempo no-escatológico. Es decir, es mirar la historia fuera de la esperanza escatológica, una historia limitada a promesas de poder terreno y de triunfos meramente humanos, es la historia de las utopías que en la modernidad han pretendido la realización de un paraíso terrestre, una plenitud sin trascendencia, un hombre autónomo, la promesa de una plenitud intra-mundana. Al contrario, Lubac advierte: "Jesús no vino a establecer un programa social que resultaría en un mundo mejor", y Hebreos anuncia: "No tenemos aquí ciudad permanente, sino que buscamos la futura" (Hebr 13, 14). A pesar de la afirmación de la Gaudium y Spes, "El mensaje cristiano no aparta a los hombres de la edificación del mundo" (G.S. 34). 
La teología de la "natura pura" que fue, a la postre, una especie de acuerdo entre el pensamiento católico y la modernidad, fue muy optimista respecto a la realización de una sociedad humana inmanente que fuera la plenitud del ser humano. Por esto mismo adolecía de cierto pelagianismo, cierto optimismo respecto a la bondad natural del hombre. En el mismo sentido se orientaron la teología progresista europea, de la cual ha podido afirmarse que Rahner y el tomismo transcendental trataron de naturalizar el sobrenatural, al contrario de la Nouvelle Théologie de Blondel, Lubac y Urs von Balthasar que trató de "sobrenaturalizar el natural". En esa misma orientación están la teología de la liberación latinoamericana y la teología liberal protestante. Esto a pesar de las tragedias de la historia y de las afirmaciones bíblicas. El N. T. habla claramente del misterio de la iniquidad enquistado en la historia. La historia de la Pasión de Jesús es un espejo y un compendio de la historia humana. El Señor Jesús bajó a los infiernos cuando fue entregado en manos de los hombres, porque entonces cayó en manos de su crueldad, sus intrigas, sus mentiras, sus miedos, sus caprichos, sus veleidades, sus traiciones, sus engańos, sus cobardías. ¿Por qué la pasión de Jesús? Porque se opuso al reino de este mundo, ejecutado sobre la idolatría del poder del hombre. El Evangelio, precisamente, al mismo tiempo que es el anuncio del Reino de Dios, es también la proclamación apocalíptica del fin del mundo creado por los ídolos: el poder del hombre sobre el hombre, el reino de la mentira y de la muerte. Ordinariamente la historia se ve como la obra del hombre, un sucederse de locuras y maldades, de torpezas y estupideces, de idolatrías ridículas. Hay una ceguera en el ser humano que no le deja ver la obra de Dios, su actividad providente y salvadora: "un velo cubre a todas las naciones" (Is 25,7). En la misma Iglesia el hombre quiere imponer su voluntad, pero Dios lucha con el hombre para salvar su Iglesia, porque si ella cae en manos de los hombres, la destruyen, según los instintos de muerte que poseen, pues lo que al fin y al cabo quieren es el triunfo de la muerte, que es su obra y su poder. Los terribles e inauditos acontecimientos del Reino de Dios no le pertenecen al mundo, no son objeto del sensacionalismo mundano, de los medios de comunicación, y sin embargo ellos son los que deciden la marcha de la historia. El mundo cuenta la historia como el sucederse de las gestas, triunfos y conquistas de sus ídolos. Es la historia de unos faraones glorificados, unas momias que son monumentos de muerte o de unos guerreros que han sembrado la muerte para imponer el poder del hombre. La historia como es contada por el mundo es una historia idolátrica. Todo el drama de la insensatez y la maldad humana se abate sobre Jesús y contra el designio salvador de Dios del cual él es portador. Desde el principio, Marcos presenta a Jesús dotado por el Espíritu para enfrentar los poderes del mal, el poder de Satán, pues contra él vino Jesús a establecer el Reino de Dios. La vida toda de Jesús, según Marcos, sirve para proclamar el Reino, está al servicio del Reino y toda la historia de Jesús es la irrupción del Reino. Este significa la ruina o destrucción total de toda la estructura del poder demoniaco que oprime al hombre, pues el mundo entero está bajo ese poder, como lo expresa claramente la primera epístola de Juan: "El mundo entero está sometido al poder del Maligno" (1Jn 5,19b).

El Reino de Dios implica la transmutación de todos los valores sociales y de la situación actual del mundo. La "basileia" anunciada por Jesús es realmente el Umwertung alle Werte (la transmutación de todos los valores) de que habló Nietzsche. Una ordenación social que supera todos los órdenes sociales realizados u utópicos soñados por el hombre, pues, en general, las organizaciones sociales políticas del mundo se establecen con base en el poder y el dominio del hombre sobre el hombre. Voltaire, personificación ideológica de la modernidad, consideraba que el progreso de la Ilustración lograría la realización plena de la sociedad meramente humana. Tal ordenación social es contraria a la que promete el Reino de Jesús: el servicio mutuo y la comunión y la aniquilación del dominio del hombre sobre el hombre. Por lo mismo, en el Reino, los que hoy son últimos serán los primeros, los que ahora son despreciados, los pobres, los 
hambrientos, los afligidos serán los preferidos en el Reino. Las utopías de la modernidad terminaron en desastre, como sabemos.

Además de leerla racionalmente, la modernidad convirtió a la historia en un museo o recuerdo del pasado muerto. El querer instalarse en el pasado es deseo de instalarse en lo muerto, pero Dios acosa al hombre con el futuro. Este ama el ayer y lo inerte, lo estático, lo que puede dominar; Dios lo inquieta con el futuro. La historia no es racional y en ella se esconde el plan de Dios, con el que no cuenta la razón moderna. De ahí el estupor, los chascos y los desencantos que deja la historia, porque ella no es como el hombre quiere que sea. Ella está llena de paradojas y "tiene un malvado sentido del humor" (Mead, 2008, 12).

Mediante el concepto de "sobrenatural histórico" entiendo la afirmación bíblica de la presencia de Dios en la historia, su acción salvífica y su lucha contra los ídolos y, además, su gobierno u orientación de la historia. Esto quiere decir que no es el hombre quien gobierna a la historia y el modo como Dios la conduce es terriblemente enigmático. Por tanto, el misterio del sobrenatural no solo es un constitutivo antropológico, sino que también es parte integrante esencial de la historia. El sobrenatural antropológico es la disposición íntima de su ser personal hacia la plenitud en el Tú de Dios. El hombre no es completamente persona sin la relación personal con el Tú de Dios que lo creó para la comunión con Él. Así mismo, la historia es incomprensible sin Él, porque Dios está en ella, es su juez y señor de la historia. El la juzga y la orienta escatológicamente. Es por esto que el paradigma cristiano de pensamiento está apuntalado por el misterio del sobrenatural. Esta realidad la argumentan de forma muy explícita dos obras de teólogos judíos: Man is not alone de A.J. Heschel y La Presencia de Dios en la historia de E. L. Fackenheim (Heschel, 1982; Fackenheim, 2002).

Dentro del movimiento de la Nouvelle Théologie han sido Jean Daniélou y Urs von Balthasar, quienes han escrito obras de teología de la historia. La de Daniélou fue traducida al inglés muy significativamente asi: The Lord of history. Reflexions on the inner meaning of history.

En obras anteriores he examinado el pensamiento griego contrastándolo con el pensamiento cristiano (Galeano, 2010; 2011). Algo que yo considero fundamental, porque en gran medida la teología cristiana se ha hecho asimilando el paradigma griego. Gran parte de la crítica de la Nouvelle Théologie a santo Tomás radica aquí, en que en algunos de sus enfoques parece más aristotélico que cristiano. Desde una óptica distinta, J.B. Metz afirma: "el pensamiento tomasiano, a pesar de su originalidad, permaneció inmerso en el horizonte conceptual griego" (Metz, 1972, 110). Ratzinger, en el mismo sentido, hace esta anotación: "Ciertamente no se puede desconocer el hecho que de facto la conciencia escatológica se oscurece en el trasfondo de la obra de Tomás” (Ratzinger, 1971, 222). Esto mismo, y todavía más ampliamente, se ve en Orígenes. Como lo anota Daniélou, fue con san Agustín que el cristianismo tomó conciencia de su visión propia de la historia y de su originalidad, una originalidad que le viene claramente del paradigma bíblico de pensamiento. Tal paradigma bíblico-cristiano dio origen al de la modernidad con su idea de progreso y sus utopías. Esto quiere decir que ambas ideas, que se volvieron contra el cristianismo, atacándolo uno de retrógrado y las utopías queriendo negar su futuro sobrenatural, tienen ambas cartas de nacimiento cristiano. Es en el paradigma histórico bíblico en el que me voy a detener a continuación.

El nacimiento de la fe en Yahvé fue un acontecimiento histórico, y la fe de Israel, como dice Buber, es un sistema de fe narrativo, o sea, un sistema de fe histórico narrativo: "El mundo de la fe profética 
es, de hecho, una realidad histórica, vista con la mirada valiente y penetrante del hombre que se atreve a tener fe". (Buber, 1960, 135). Esa fe es el "insight" que penetra hasta el Misterio oculto en la historia. Von Rad explica que la fe, tal como la presenta Isaías, es saber ver el obrar histórico y salvífico de Yahvé: "pero no ven la obra de Yahvé, y no ven el quehacer de sus manos" (Is. 5,12). Heschel destaca que "el logro principal de la religión bíblica fue el de quitar el velo de anónimo de las obras de la historia. No hay leyes últimas, ideas eternas. Solo el Señor es último y eterno". (Heschel, 1973, 1079). O como dice otro teólogo judío, E.L. Fackenheim: "El Dios que es Señor de la historia era, es y será soberano como Poder único", a lo cual agrega: "El pueblo judío nació de las experiencias radicales de una Presencia divina que salva y gobierna”(Fackenheim, 2002, 69).

En el Sinaí se estableció la relación de Yahvé con Israel, es decir, la fe de Israel. Comenzó así el drama de la historia, llena de idolatría, violencia y crueldad, pero también donde se dejan sentir los sentimientos de amor y sufrimiento de Dios, una historia "llena de sufrimiento injusto", dice Fackenheim (tanto para Dios como para el hombre, agregamos nosotros). ¿Será por eso que es mejor mirar la hermosa armonía de la naturaleza que mirar la historia? ¿Refugiarse en la especulación antes que mirar los hechos? ¿O contar la historia centrada en los héroes idealizados y no mirar la historia de "los humillados y ofendidos de la historia"? "La historia no es un conglomerado de hechos neutrales, sino un drama que describe la relación entre Dios y el hombre... Hay una furiosa batalla: el hombre, en su presunción, intenta modelar la historia sin consideración y desafiando a Dios... Pero Dios lucha con el hombre" (Heschel, 1973, 61). Aquí radica la seducción del logos y de los ídolos. Presuntamente, allí se encuentra la salvación del caos de la historia y se podría dominar la realidad mediante las ideas. La prohibición de los ídolos y hacerse imágenes significaba no adorar ninguna criatura del mundo, ni siquiera a Yahvé en forma de criatura. Se trata de un mandamiento liberador: el hombre no está sometido a ninguna criatura, solo al Creador. Pero se trata también de un llamamiento al realismo y al reconocimiento del sentido de la historia, pues hay Alguien que está primero en el mundo y en la historia: "En la Biblia la realidad de Dios vino primero, y la tarea era cómo vivir de una manera compatible con Su presencia. La coexistencia del hombre con Dios determina el curso de la historia”. (Heschel, 1973, 55).

"Así dice el Señor: buscadme y viviréis" (Am 5,4). Buscar al Señor es tratar de escucharlo en los acontecimientos: Él habla allí. Fue en los acontecimientos donde los profetas pudieron escuchar la Palabra de Dios. Porque la Palabra de Dios son hechos: "El habló y así fue, él lo mandó y se hizo" (Sal 33, 9; Is 55,11). No es solo que Dios está presente en la historia, es que también actúa en ella mediante su Palabra, más aún, la Palabra es creadora de historia. O como dice von Rad, "la historia se hace palabra y la palabra se hace historia" (von Rad, 463). En Mateo, Jesús dice todavía más: "La sabiduría de Dios se demuestra en los hechos" (Mt 11,19b). O como lo expresa Pablo: "El Reino de Dios no se demuestra en palabras sino en hechos" (1, Cor 4,20). Y es que el lenguaje de Dios es el de la historia, el de los hechos. Dios expresa su voluntad históricamente. Así mismo, la revelación en el sentido bíblico no son apariciones epifánicas, son hechos, acontecimientos. El conocimiento de Dios se obtiene en experiencias históricas. De aquí la constante afirmación bíblica "y sabréis que yo soy Yahvé (Ez 20,38). ¿En qué? En los hechos. Isaías se hace eco del lamento de Dios porque su pueblo no lo ha conocido en sus obras: "No contemplan la obra del Señor, no ven la obra de sus manos" (Is 5,12b).

Todos los desastres de la historia nacen de la idolatría, pero ¿qué es la idolatría? El dios-espacio o las fuerzas cósmicas, la fatalidad o el destino, pero también el poder de los pueblos deificado. En consecuencia, 
la historia está jalonada por los momentos de caída y ruina de los ídolos, y por los kairoi de Dios o hechos y momentos de gracia y salvación, pues el Señor tiene sus momentos en la historia para destruir los ídolos que personifican el poder de las naciones, pero también tiene sus momentos de salvación. El profeta, precisamente, es el que anuncia o proclama lo que Dios está haciendo en la historia. El hombre hace planes de acuerdo con sus dioses, pero el Señor de la historia es Yahvé: "El Señor deshace los planes de las naciones, frustra los proyectos de los pueblos. Pero el plan del Seńor subsiste por siempre” (Sal 33,10-11).

¿Esto qué significa? Que, aunque la historia aparece caótica, hasta el grado que la indeterminación que existe en lo cuántico se da también en la de la historia humana, hay en ella un "orden divino" (Richard, 1966, p. 228), un "ordo supernaturalis gratiae”, en palabras de Mons. Conrado Martin Obispo de Paderborn en 1870, en el Concilio Vaticano I. Este es el gran misterio de la historia: la presencia del Señor en ella, su acción salvadora del hombre y destructora de los ídolos, los planes humanos que van en contra de la voluntad de Dios. Por esto mismo, la obstinación del hombre contra Dios se presenta hasta en las íntimas profundidades de la historia. Todos los desastres de la historia nacen de la idolatría, que ocasiona la ira de Dios, esto es, su alejamiento y abandono del hombre a sus propios caprichos y mentiras. Cuando Dios se aíra "esconde su rostro", realidad que atormentó a Job: “¿Por qué me ocultas tu rostro?" (Job 13,24). El Salmo 81 da esta respuesta: "Mi pueblo no me escuchó, Israel no me obedeció; así que los abandoné a su corazón obstinado, para que caminasen según sus antojos" (Sal 81,12-13). Se trata de un Dios celoso que ante la idolatría esconde su rostro y abandona al hombre a las consecuencias de su idolatría: "Aquel día montaré en cólera, los abandonaré y les ocultaré mi rostro. Serán pasto y presa de un sinfín de males y adversidades... Yo ocultaré mi rostro aquel día, a causa de todo el mal que habrán hecho, yéndose detrás de otros dioses" (Deut 31,17.18).

Las relaciones de Yahvé con su pueblo fueron unas relaciones de fe, muy particulares, por tanto, llenas de conflictos, dramas y angustias que le hacían ver a ese pueblo lo doloroso que es alejarse del Señor: "Tu propia maldad te castigará, tu propia apostasía te escarmentará. Aprende que es amargo y doloroso abandonar al Señor tu Dios, y no reconocerlo, dice el Señor Dios omnipotente" (Jr 2,19). Isaías, a su vez, advierte: "los que abandonan al Señor perecerán" (Is 1,28b; Sal 73,27). Sin embargo, el plan Salvador del Señor no se frustra, pues tiene una continuidad histórica escatológica, según la cual un acontecimiento salvador anuncia otro que se avizora en el futuro. El proceso escatológico va creciendo gradualmente en la historia, de tal manera que la actuación de Dios en el A.T. se orienta escatológicamente hacia el acontecimiento Cristo-Iglesia. La historia, en la Biblia, está contada con vistas al futuro, o en palabras de Bultmann, con "una apertura radical hacia el futuro". (von Rad, p. 466). La obra salvadora viene desde el tiempo de Israel, alcanza su centro, su culminación y su sentido en la persona y la obra de Jesús, en su predicación, su evangelio, sus milagros, su muerte y su resurrección. Esa obra la sigue realizando el Señor en la Iglesia y por medio de ella. Así que podemos afirmar que la Iglesia es la interpretación histórico-salvífica del A.T. a la luz del acontecimiento Cristo. La relación entre el A.T. y el N.T. no es solamente conceptual o cultural; es, ante todo, histórico-salvífica. Los hechos del A. T. culminan en el N.T. son su fruto. Como lo indica von Rad, los profetas realizaron una obra hermenéutica que consistía en una actualización continuada de los hechos salvíficos antiguos para interpretar los nuevos dentro de las situaciones que en el ahora se estaban dando. Es por eso que "la esperanza de Israel tuvo que desplegarse siempre hacia más adelante" (von Rad, p. 413). Agrega von Rad que "el A. T. ... refleja una serie continua de nuevas revelaciones y disposiciones divinas, junto con sus actualizaciones siempre nuevas" (von Rad, p. 422). Es con este método hermenéutico que los autores del N.T. leyeron el A. T., pues los acontecimientos asombrosos de Cristo y de la Iglesia 
produjeron una nueva lectura e interpretación del A. T. O sea, el N. T. es una lectura hermenéutica del A.T. Esto es posible porque la vida de Jesús es la continuación y culminación de la vida de Israel, su sentido propio y su explicación, y la obra salvadora que viene desde los comienzos de Israel continúa y culmina en Jesús, para difundirse a partir de él en el mundo entero mediante la Iglesia: "El Nuevo Testamento, partiendo de un acontecimiento totalmente nuevo, realiza una vez más la interpretación de la historia de Dios veterotestamentaria" (von Rad, p. 466).

La palabra que designa a Dios como Yahvé tiene el significado de un verbo: Yahvé es aquel que estará allí, que estará presente. El Dios de Israel no es un Dios de la naturaleza, sino el Dios de la historia, que se revela en la historia y guía a su pueblo por la historia. Yahvé quiere decir el que actúa en la historia. Se da entonces el paso del Dios del cosmos al Yahvé de la historia y comienza la lucha del Dios de la historia contra los Baales o Dioses de la naturaleza, contra lo que Él no es. De esta manera, Israel historizó la naturaleza y fue así como historizó las "fiestas que en otro tiempo eran puramente agrícolas" (von Rad., p. 137). O sea, Yahvé se revela en la historia y los Baales son fuerzas cósmicas naturales idolatrizadas. Los pueblos antiguos pensaban el tiempo y la historia en función del ritmo de la naturaleza, que es cíclico. Pero ahora nace una realidad histórica desligada de la naturaleza, el pueblo de Israel, y comienza una relación personal dramática: la relación de Yahvé con su pueblo. La formación del pueblo de Israel fue un proceso histórico, así mismo se ha ido dando la formación de la Iglesia. Israel nació de un acontecimiento histórico salvífico en el que Dios se reveló y con lo cual Él se manifestó. En esa historia, en esos acontecimientos, liberación de Egipto, peregrinación por el desierto, Sinaí, Israel descubrió a su Dios. Por eso, la gran sabiduría bíblica es conocer la obra de Dios en la historia.

Es claro, entonces, que la historia de Israel es también la historia de la lucha de Dios para que el hombre asuma la historia, pues el hecho es que se percibe una fuerte tendencia a huir de la historia y a replegarse en la abstracción o en realidades meramente pensadas: "El desprecio al tiempo parece ser la característica del pensamiento humano casi por todas partes”, señala Heschel (Heschel, 1955, p. 205). Así mismo, "el culto arcaico es por esencia antihistórico (von Rad, p. 142). Mircea Eliade dice también que al estudiar las sociedades arcaicas algo que le ha llamado particularmente la atención ha sido "su rebelión contra el tiempo". (Eliade, 2009, p. 9) y su hostilidad a la historia, su esfuerzo por no tenerla en cuenta. Se detecta en las culturas primitivas la nostalgia del arcano ancestral, por lo que se busca abolir el tiempo y la historia mediante mitos arcaicos. La preocupación de los profetas fue escuchar y escrutar los hechos de la historia. El hombre no está solo ni en el cosmos ni en la historia, pero se obstina en hacer una historia en la que él es todo, autónomo y autosuficiente, y se esfuerza por poblar el cosmos con seres imaginarios a los que él, al final, supuestamente vencerá con su poder.

El Yahvista corta con las narraciones cosmogónicas y las hace historia y esto de tal manera que el cosmos, la tierra está sometida a la historia y desligada del mito cosmogónico. Yahvé no es un dios que exprese los poderes cósmicos, sino que es un peregrino con su pueblo y un guerrero. Él es el Dios que ha vencido a los monstruos marinos y al caos o dragón primordial de la naturaleza. Pero, así como ha vencido al caos primordial para crear el cosmos, así también vence el caos de la historia para crear su Iglesia.

Esta lucha contra la idolatría de origen cosmológico tiene otra consecuencia crucial: el Dios bíblico no es algo cósmico sino que es una persona, por lo tanto, la relación con Él no se establece por medio de ritos o cultos mágicos, sino que es lo que expresa el profeta Oseas con el término conocer y que según Buber 
significa "reciprocidad en la relación entre Dios y el pueblo" (Buber, 1960, p. 115): "Quiero misericordia y no sacrificios, conocimiento de Dios más que holocaustos" (Oseas 6,6). El culto bíblico, en cambio, es histórico. Las fiestas cristianas y los sacramentos cristianos están ligados a acontecimientos históricoescatológicos, no a los ritmos cósmicos o a mitos primitivos.

Ligado al culto idolátrico estaba el culto al sexo, como poder autónomo e independiente de Dios. La lucha contra los baales y los cultos de fertilidad significa liberación del hombre de las fuerzas sexuales, pues, así como no es esclavo de las fuerzas cósmicas tampoco lo es de las sexuales. "El cultivo de la tierra por los cananeos tenía, aparentemente, profundos vínculos de tradición con los mitos y ritos sexuales; en tanto que Yahvé por su propia naturaleza está por encima del sexo, y no puede tolerar que el sexo, como toda vida natural deba ser reverenciado como Él... La base sexual del misterio de la fertilidad, oculto en la mezcla del agua y de la tierra, debe ser abolida. La irrigación natural no es la obra de la unión de un elemento fuente masculino con un elemento acogedor femenino, sino el don de la divinidad que da, el Señor de toda fertilidad" (Buber, 1960, p. 75). Es por eso que liberar a Israel de los baales es liberarlo de la sujeción a las fuerzas naturales o cósmicas, porque es Yahvé quien tiene el poder sobre las fuerzas del cosmos, la naturaleza y la vida que brota del sexo. La protesta contra la práctica de Israel de la religión de la naturaleza y los ritos cananeos de la fertilidad es particularmente manifiesta en Oseas, quien para referirse a ella acuñó el término de prostitución: "Israel ha abandonado a Yahvé como una mujer infiel corre tras su amante". (von Rad, 2009, 179). Leer la historia de Israel en el A. T. es descubrir el amor herido de Dios. El hombre primitivo idolatrizó el sexo, como idolatrizó las fuerzas de la naturaleza, mientras que el hombre de la modernidad lo secularizó y lo banalizó. En ambos casos el hombre intenta desligar el sexo, una realidad que expresa el amor humano y es transmisora de la vida, de Dios, fuente del amor y de la vida.

Esta afirmación: el Señor del cosmos y de la naturaleza es Yahvé y no los baales, es reafirmada por la revelación en la montaña del Horeb del Sinaí a Elías: Dios no está ni en la tormenta ni en el fuego, sino en la voz de un "silencio suave" (1Re 19,12). Elías "demuestra que las aguas arriba están en las manos de Yahvé. No Baal sino Yahvé es el Señor de la tierra” (Buber, 1960, 80). Esto que ocurrió en el Sinaí es precisamente la revelación: que Dios está en la historia, actuando en ella y que, por tanto, no se reduce a ser la suma de las fuerzas naturales las cuales el hombre puede manipular, ni tampoco está replegado en el más-allá, donde el hombre quisiera que estuviera. Yahvé significa que Dios está presente en la historia. Pero, además, la tendencia idolátrica de Israel, su baalización, tiene por fin ganarse el favor de los poderes de los pueblos vecinos, el poder humano. Muchos reyes de Israel baalizaron a Yahvé en su intento de utilizarlo como poder humano, porque para el hombre, que ama adorar la obra de sus manos, "su poder es su dios" (Hab 1,11b). Por eso la queja de Dios en Jeremías: "me han dejado a mí para ofrecer incienso a otros dioses y adorar la obra de sus propias manos" (Jer 1,16). De aquí la pregunta básica que plantean los profetas: ¿en qué poder te apoyas, en el de los hombres o en el Señor tu Dios? Confiar en el poder humano es confiar en el ídolo y desconocer que quien determina el destino de los pueblos es el Señor de la historia. Sobre lo cual advierte el Salmo 118 de esta manera: "Mejor es refugiarse en el Señor que fiarse de los hombres" (Sal 118,8). Puesto que el hombre idolatriza su propio poder, la destrucción de los ídolos será el fin del poder del hombre: "Las naciones verán y se avergonzarán de toda su prepotencia... Lamerán el polvo como la serpiente" (Miq 7,16.17). Pero, además, el que confía y se refugia en el Señor no les teme a los poderes humanos, que siembran la historia de terrores: "que el hombre hecho de tierra no vuelva a sembrar su terror" (Sal 10,18b), y agrega el libro de los Proverbios: "Es engańoso temer a los hombres, quien confía en el Señor vive seguro" (Pr 29,28). 
Hay una lucha de Dios contra los ídolos, pero también la historia está atestada de las luchas de los ídolos entre sí. Tal lucha se ha dado con consecuencias siniestras en los tiempos modernos. La modernidad europea creó dos ídolos que se enfrentaron entre sí de manera monstruosa. Uno fue el dios burgués o el dios de la razón que se enfrentó al dios del marxismo, ambos en su enfrentamiento produjeron dos guerras mundiales de consecuencias catastróficas y ambos se desplomaron dejando en sus adoradores un sentimiento de angustia y sin-sentido de la vida. A ambos los traicionó la historia, a Marx y a la modernidad de la Europa continental, si es que se puede decir que la historia traiciona y no que Marx y la modernidad pretendieron que la historia les obedeciera y por eso fueron ellos los que la traicionaron.

En conclusión, se puede decir que en la lucha de Dios contra los ídolos se centra la historia de Israel, la historia bíblica, pero también la historia de la Iglesia. Esta lucha, por lo demás, es la obra salvadora de Dios, porque la salvación es liberación de la opresión que ejercen los ídolos sobre el hombre, la salvación es la caída de los dioses. Los primitivos encontraban la salvación en el tiempo mítico primordial o arcaico, al cual se accedía mediante los ritos. La salvación era cósmica. Es decir, se obtenía la salvación huyendo del tiempo y de la historia hacia lo primordial ancestral mediante rituales. El contraste con la fe bíblico-cristiana es total. En las religiones se huye del tiempo para encontrar la salvación. En Israel y el cristianismo, Dios irrumpe en el tiempo histórico para salvar al hombre. Aquí la salvación no es huida sino encuentro personal.

Para la Biblia, la salvación son hechos históricos, y no es un solo hecho, sino una sucesión de hechos en los que el Señor va realizando la obra de la salvación, pues a cada hecho salvífico sucede uno nuevo, y cada hecho salvífico realizado abre el horizonte a otro. Esto es lo que hace que la salvación sea históricaescatológica y no el vuelo del alma hacia otro mundo. Von Rad anota, a este propósito, que "el Antiguo Testamento no puede leerse más que como el libro de una expectación que va siempre creciendo hacia lo inaudito". (von Rad, 2009, 413). La liberación de Egipto y el paso del mar Rojo es el comienzo de una salvación que irá creciendo en los siglos hasta la Parusía. Las mirabilia Dei del A. T. y las del N.T. hacen parte de la misma economía de salvación. Esta constituye una sucesión ordenada de acontecimientos que se realizarán plenamente en la consumación de todas las cosas en Cristo.

Es preciso, entonces, distinguir entre el sobrenatural como acción de Dios y la sobrenaturalización de los fenómenos o terrores cósmicos y los terrores, creados por el hombre. El hombre sobrenaturaliza los terrores e intenta confundirlos con el sobrenatural salvífico de Dios. Esos terrores sobrenaturalizados son ídolos que el hombre adora con terror reverente. Los terrores históricos, homicidios, guerras, violencias, masacres, genocidios, son los monstruos o bestias que el hombre produce para hacer reinar la muerte y someter a esclavitud a su prójimo. Sin embargo, el Seńor de la historia domina los terrores de la historia, vence a las bestias del hombre y las pone a su servicio. Uno de los hechos más grandiosos de la historia, cantado por el libro del Apocalipsis, es el triunfo y dominio del Señor sobre los terrores de la historia: "Vi entonces a la Bestia y a los reyes de la tierra con sus ejércitos, reunidos para entablar combate contra el jinete del caballo blanco y contra su ejército. Pero la Bestia fue capturada, y con ella el falso profeta... Los dos fueron arrojados vivos al lago de fuego... Los demás fueron exterminados por la espada que sale de la boca del que monta el caballo" (Apoc 19,19-21). ¿Quién es el que monta el caballo? Lo dice antes el mismo Apocalipsis: "Entonces vi el cielo abierto donde había un caballo blanco. Su jinete se llama "Fiel" y "Veraz", y juzga y combate con justicia... y se llama "Palabra de Dios" (Apoc 19,11.13). 


\section{El sobrenatural histórico como humus de la Iglesia}

"La Iglesia no es solo una realidad empírica y humana, ella es también una realidad histórica. Es un fenómeno en y de la historia”.

"La Iglesia cristiana surgió en la historia como producto del desarrollo histórico. No surgió a la existencia de una vez sino en un prolongado periodo de tiempo". (Haight, s.J., 2004,p.37 y p. 69).

El Vaticano II llama a la Iglesia "sacramento universal de salvación" (G.S. 45), es decir, signo visible de la misteriosa obra de la gracia, del misterioso actuar de Cristo en la historia. Por su parte, san Agustín la presenta como el Cristo extendido por toda la tierra, como "un solo hombre que se extiende hasta el fin del mundo" (In Ps. 85,5), “cuya cabeza se halla en el cielo y los pies en la tierra” (In Ps. 90, II, 8), puesto que "la unidad de todos los cristianos es un hombre" (In Ps. 29, II, 5). Por esto mismo, "lo que padeció Cristo lo padece la Iglesia; lo que padeció la cabeza lo padecen también los miembros" (In Ps. 40,8). De esto se puede concluir que la obra evangelizadora de Jesús la continúa la Iglesia y, mediante ella, Cristo sigue realizando su obra, que es la prolongación del misterio de Jesucristo en la historia, de su ser y de su actuar. Por esto mismo, "Evangelizar constituye, en efecto, la dicha y vocación propia de la Iglesia, su identidad más profunda. Ella existe para evangelizar" (Pablo VI, N. 14, 1986).

En el evangelio de Juan, Jesús declara: “Mi Padre está actuando, y yo también estoy actuando” (Jn 5,17). Ya lo había anunciado Isaías: "El Señor se levanta... el Señor luchará... para realizar su obra... para completar su obra, su misteriosa obra” (Is 28,21). A la vez que el tercer Isaías proclamó su carácter oculto: "El ojo no ha visto, Oh Dios, lo que Tú has preparado para los que te aman" (Is 64,4). Pablo se presenta como servidor de la Iglesia para dar a conocer ese misterio: "He sido constituido servidor de la Iglesia mediante la misión que Dios me concedió, dar cumplimiento a la Palabra de Dios, manifestar el misterio escondido desde siglos y generaciones" (Col 1,25-26).

Esa obra de la evangelización se orienta a la edificación del Cuerpo de Cristo. Como lo asegura Pablo, "Todo está orientado a la edificación del Cuerpo de Cristo" (Ef 4,13b). Esa edificación ya tiene su soporte: "Conforme a la tarea que Dios me confió, yo, como buen arquitecto, puse los cimientos... Nadie puede poner otros cimientos que los ya puestos: Jesucristo" (1 Cor 3,10.11; cfr. Ef. 2:20). El mismo Pablo da gracias al Señor por haberlo integrado a esa tarea: "Doy gracias a nuestro Señor Jesucristo, porque me ha revestido de fuerza para cumplir mi tarea, trabajar por él” $(1$ Tim 1,12$)$.

Así que se puede afirmar que la obra más prodigiosa del Señor en la historia es la Iglesia. Es algo fascinante, deslumbrante: el mundo no ve ni comprende y mucho menos los sabios y poderosos de este mundo, lo que es la obra de construcción de su Iglesia que el Señor está realizando. La carta a los Efesios explica que los cristianos son integrados en esa construcción "que tiene por fundamento a los apóstoles y a los profetas, y cuya piedra angular es Cristo mismo, en quien toda la edificación bien trabada se eleva hasta formar un templo santo en el Señor" (Ef2,20-21). Por su parte, la primera de Pedro los invita a dejarse integrar en esa construcción: "como piedras vivas", pues se trata de "la construcción de una casa espiritual para un sacerdocio santo, a fin de ofrecer sacrificios espirituales agradables a Dios por medio de Jesucristo" (1Pet 2,5). Y san Agustín: "La casa que ahora se edifica será dedicada o consagrada más tarde. Ahora se fabrica la casa, es decir, la Iglesia; más tarde se dedicará”. (In Ps. 29, II,6). 
Newman constata que "Un acontecimiento sobrenatural secreto se desarrolla bajo la apariencia visible de este mundo". Por lo que también dice Congar que la profundidad de la Iglesia es insondable, y es que su misterio está "escondido con Cristo en Dios". Así que su naturaleza no puede ser sondeada por nuestros débiles esfuerzos intelectuales. Y es que ella es un don divino fundada en Cristo y realizada en la historia humana, y por ella la gracia de Dios es mediada para la salvación de la humanidad. Su identidad esencial le es dada por el Seńor, ella no se da a sí misma el ser, ni su forma, pero tampoco se gobierna a sí misma, como tampoco mantiene su existencia por sí misma: depende totalmente del poder del Espíritu del Señor. La estructura y la misión de la Iglesia, su ministerio ordenado de obispos, presbíteros y diáconos; su naturaleza y sus funciones; el mandato de evangelizar, celebrar los sacramentos, la asistencia pastoral y la asistencia a los fieles, todo esto se deriva de las Escrituras según han sido entendidas e interpretadas a través de la historia de la Iglesia.

Por lo demás, la edificación de la Iglesia no se realiza sin ataques y oposiciones de todo género, desde adentro y desde afuera. A la Iglesia como al cosmos la afectan también la entropía y la inercia. La edificación del templo de Jerusalén fue figura de la edificación de la Iglesia. Esdras cuenta que "el pueblo de la tierra se puso a desanimar a la gente de Judá y a atemorizarla para que no siguiesen edificando. Sobornaron contra ellos a algunos consejeros para hacer fracasar su proyecto" (Esd 4,4-5). El Salmo 33 proclama: "El Señor aniquila los planes de las naciones, frustra los proyectos de los pueblos, pero el plan del Señor subsiste para siempre" (Sal 33,10-11). Todo cuanto hemos venido diciendo lo expresa así el Salmo 46: "Las aguas de una fuente recrean la ciudad de Dios, Santifican la morada del Altísimo. Dios está en medio de ella, por eso no vacila nunca; Dios la socorre al despuntar la aurora. Los pueblos se enfurecen, los reinos se tambalean. La voz del Señor resuena, la tierra se deshace. El Señor de los señores está con nosotros, El Dios de Jacob es nuestro baluarte. Venid a ver los prodigios del Señor, El llena la tierra de estupor" (Sal 46,5-9).

La Iglesia es la morada de Dios, "la construcción de sólidos cimientos, cuyo arquitecto y constructor es el mismo Dios” (Heb 11,10), que Él se está edificando con los hombres, y de la que estos, por su fe, son piedras vivas del edificio (1Ped 2,5). Ella es obra de Dios en la historia según el plan eterno en Cristo, es decir, según el proyecto eterno de Dios para realizarlo en la historia. Este es el gran misterio de la creación y de la historia. Esta construcción, como la del templo de Jerusalén, pasa por momentos trágicos y dramáticos unas veces, críticos y muy críticos otras, pero que las convulsiones y desastres de la historia no logran arruinar. Tenemos entonces que la Iglesia es una realidad histórica, como lo es el cosmos que desde hace 14.000 millones de años vive un proceso histórico evolutivo que es bastante dramático. Así, la Iglesia, como también el cosmos, es en su realización histórica un drama, a menudo trágico. Como lo dijo el cardenal Döpfner en el Concilio: "el misterio de la cruz está siempre en el corazón de la Iglesia" (Lubac, 1967, 18).

Para referirse a ella teológicamente se ha utilizado gran cantidad de expresiones (Dulles S.J., 1975). Se refieren a ella como sociedad jerárquica, como una comunidad de carismas, como una comunidad ecuménica o la comunidad de la Palabra, la comunión de santos y creyentes o comunidad de los justificados, el icono de la Santísima Trinidad, el Cuerpo místico de Cristo, el sacramento del Espíritu Santo, el Misterio de Jesucristo que vive y se prolonga en la historia, el pueblo de Dios peregrino, templo de Dios o casa de Dios, la esposa de Cristo, una comunidad histórico-escatológica o la comunidad escatológica de salvación. Tan numerosas expresiones dan cuenta de su inmensa riqueza espiritual y de su profundidad constitutiva, al mismo tiempo que revela la imposibilidad de dar de ella una definición satisfactoria. 
El hecho de considerarla en proceso de realización quiere decir que ella no es algo ya hecho, o sociedad perfecta, sino que se está haciendo. El desarrollo es un constitutivo esencial de su ser en este mundo. Ella "crece visiblemente en el mundo" (Vaticano II, L.G. n. 3).

Ella se transforma mediante formas sociológicas o paradigmas nuevos, uno fue el paradigma patrístico, otro el medieval, después vinieron los del barroco y el de la modernidad, otro es el de la postmodernidad, que está en pleno proceso de realización. El paradigma eclesial barroco colapsó con el Vaticano II. Desde entonces la Iglesia está adquiriendo un paradigma nuevo. Esto significa también que la imagen perfecta de la Iglesia y su identidad no están en el pasado, sino que son escatológicas, y que, por tanto, su reforma o renovación no está en recuperar la forma antigua, así sea la apostólica, sino en la fidelidad al Evangelio, al proyecto de Dios en Cristo y al Espíritu de Dios que la anima. La Iglesia se realiza en la historia, y esta es dinámico-evolutiva. Por eso, el desarrollo es un constitutivo esencial suyo y precisamente por su historicidad, las funciones y las estructuras eclesiales no permanecen estáticas. Como dice el Vaticano II, "la Iglesia... llegará a la perfección en la gloria, al final de los tiempos" (Vaticano II, L.G. n. 2).

Esta transformación tampoco está dictada por el mundo, sino que responde al "misterio mantenido en secreto durante siglos en Dios" (Rm 16,25; Ef. 3,9). La Iglesia es una aventura escatológica que marcha hacia su plenitud en el Reino de Dios. Aparece en el mundo como una realidad histórico-social dotada de una fuerza vital sobrenatural que la proyecta hacia el futuro. Su desarrollo histórico, los distintos períodos que ha vivido van desplegando lo que ella es y cómo ha ido realizándose. Algunos de los cambios formalizados por el Concilio en la visión de la Iglesia han tenido por consecuencia una verdadera revolución copernicana en la eclesiología católica, puesto que el catolicismo barroco y de la modernidad fue zarandeado por el Vaticano II mediante el aggiornamento. Quizá el aporte más valioso del Vaticano II, desde el punto de vista de la eclesiología, es haber colocado a la Iglesia en su fundamento: el misterio es la roca, las formas sociológicas pueden cambiar y de hecho cambian constantemente, pero la roca en la que se edifica permanece: "Por muy arraigada que esté [la iglesia] en la historia, ella no es esclava de ningún tiempo, ni de nada cuya esencia sea temporal. El mensaje que transmite y la vida que propaga no son jamás solidarias de un régimen político, ni de un estado social, ni de una forma particular de civilización... Ella no está fundada en otra roca fuera de la fe de Pedro, que es la fe en Jesucristo" (Lubac, 1968, 234).

En el trasfondo de las declaraciones conciliares se percibe el cambio de paradigma cultural, o sea, el paso del paradigma abstracto-especulativo al histórico-concreto, e igualmente se puede ver el paso de una presentación conceptual e institucional-jurídica de la Iglesia a una comunitaria y pastoral. En esta perspectiva está también la conciencia de que la verdad es histórica y que lo doctrinal en la Iglesia no es lo más importante ni lo más decisivo, sin dejar de ser importantes. La tarea de la Iglesia y la evangelización no consiste en proclamar verdades ahistóricas y abstractas, o normas morales pertenecientes a una determinada ideología, y la tarea de la teología no consiste en especular y crear sistemas ideológicos. Porque como afirma Lindbeck (Lindbeck, 2002), la Iglesia no tiene su legitimación en logros morales, sino en la fe, su identidad se la da la elección de Dios, no su fidelidad, que, por lo demás, es deficiente. La misma imagen de Jesús que creó la modernidad era la de un afable rabino maestro de ética, y por lo mismo quiso que la Iglesia fuera una institución al servicio de la moral social racional de la modernidad. De ser evangelizadora y proclamadora del kerigma, la modernidad la quiso reducir a ser una institución al servicio de su ética. 
Para las eclesiologías de la posmodernidad, un tema central es la comprensión de las relaciones de la Iglesia con el mundo, el cual implica el tema de las relaciones entre naturaleza y gracia. Algunas de las teorías de la posmodernidad muy influyentes son las de Wittgenstein, el neopragmatismo de Richard Rorty y el estructuralismo lingüístico, así como el desconstructivismo de Jacques Derrida (Connor, 2004; Vanhoozer 2003; Ward, 2005; Scott, Cavanaugh, 2004). Pensadores destacados de esta tendencia posmoderna en teología son: Jean-Luc Mario, considerado un teólogo posmetafísico, Graham Ward, John Milbank, Stanley Hauerwas y Catherine Pickstock. Milbank, líder de la llamada Ortodoxia radical, afirma la superioridad de la metanarrativa cristiana, que no tiene que justificar sus pretensiones ante la razón. Para muchos críticos, las eclesiologías de Hauerwas ${ }^{2}$ y la Ortodoxia radical promueven una mentalidad de ataque contra el mundo. Por otra parte, están los teólogos postliberales George Lindbeck, Robert Jenson, John Howard Yoder, Daniel Hardy y David Ford.

Mientras que el protestantismo afrontó y, en parte, se dejó anegar por la marea de la modernidad en su versión del capitalismo liberal anglosajón, la iglesia ortodoxa oriental estuvo oprimida por la otra ideología de la modernidad: el marxismo, una ideología de la modernidad continental europea. Sufrió una cautividad brutal pero no fue aniquilada. La Iglesia católica, a su vez, ha tenido que afrontar ambas ideologías y su lucha ha sido intensa, pero ni el liberalismo ni el marxismo han sido capaces de acabar con ella. En cambio, el marxismo sufrió una implosión que lo desplomó, y el liberalismo moderno está siendo superado por el llamado post-liberalismo. Esto no quiere decir que no le hayan causado dańos terribles a la Iglesia católica. Pero la historia muestra su resiliencia constitutiva, y, como dice Pablo, "atribulada en todo, pero no aplastada; apurada, pero no desesperada; perseguida, pero no abandonada; derribada, pero no aniquilada" (2, Cor 4,8-9).

Apreciada solamente desde el punto de vista externo, la Iglesia católica se ve como una realidad socio-religiosa inmensamente grande, unida, pero no monolítica, diversa, pero en comunión y con un intenso "elan" universalista y misionero. Posee una vasta esfera de influencia en el mundo actual. Su red de parroquias, escuelas, universidades, centros misioneros y centros de servicio social se extiende por todo el mundo, pues la Iglesia tiene presencia en todos los continentes. Aclarando que no son los números estadísticos los que evidencian el valor o la verdad de la Iglesia, el hecho es que el número de católicos es mayor que el número de protestantes y ortodoxos orientales juntos. En los Estados Unidos, un país predominantemente protestante hasta hace algunos años, los católicos constituyen la denominación cristiana y religiosa más numerosa (pues pasa de 74 millones) en tanto que la segunda, los bautistas del sur, cuentan alrededor de 14 millones. En los siglos XIX y XX, la discriminación contra la minoría católica en los Estados Unidos llevó a la Iglesia a crear una especie de sociedad paralela, de tal manera que hoy hay en ese país alrededor de 6.800 escuelas católicas, 630 hospitales, un número similar de centros de salud y 244 colleges y universidades. Muchas de estas instituciones están entre las mejores de ese país.

2 Stanley Martin Hauerwas, teólogo norteamericano, profesor en las universidades Duke, Aberdeen y Notre Dame. Escribe especialmente sobre ética y teología política. Algunas de sus obras son: Against the Nations: War and Survival in a Liberal Society, A Community of Character: Toward a Constructive Christian Social Ethic, In Good Company: The Church as Polis y A Better Hope (2000). Rechaza la teología liberal y el liberalismo de la modernidad, al que critica por lo que él llama su "racionalidad desencarnada" y su idolatría de la teoría y por ignorar la contingencia de la historia, la tradición y el último telos de la vida, con el fin de propiciar la autonomía. 
La influencia de la Iglesia católica es incalculable en los campos de la política, la economía, la historia, la ciencia, la educación, la teología, la filosofía, la literatura y el arte, particularmente en Europa y en las Américas, al punto que es considerada como "la más formidable institución religiosa en la historia de América y del mundo".

Pero no es aquí, en su aspecto externo, donde radica la grandeza, el poder y el valor de la Iglesia. Es en su intensa vida espiritual, en su historia dramática y trágica, pero también asombrosa, en su ser interior, en su misterio, es donde se enraíza el inestimable tesoro de la Iglesia y toda su grandeza. Su riqueza se llama Jesucristo y cuando se ahonda en el misterio de la Iglesia se siente latir en ella ese misterio. Pablo dice: "Este es el misterio: Cristo habita en ustedes, él es la esperanza de la gloria" (Col 1,27). Es Él en el que ella se arraiga y del cual ella se alimenta, porque de Él manan su vida, sus sacramentos, su Palabra, su liturgia, su obra evangelizadora. Ese misterio permea totalmente a la Iglesia. Es decir, el misterio de Jesucristo es el que causa, estatuye, define y formaliza a la Iglesia. Este misterio es la fuente de su actividad toda. La Comisión Teológica Internacional declara: "Su naturaleza está fundada en el misterio de la persona de Jesucristo y de su obra de salvación” (Comisión Teológica Internacional, 1978, n. 5). Afirmar que la Iglesia es un misterio quiere decir que ella es una de las acciones maravillosas de Dios en este mundo, ella es obra de Dios.

Se trata de una realidad histórica, palpable entre los fenómenos de este mundo, y sin embargo no es algo ya dado plenamente. Es un organismo vivo que evoluciona y crece. Esto ocurre por medio de los acontecimientos de la historia, guiados providencialmente por el que es su Cabeza, Cristo: "de quien todo el cuerpo recibe trabazón y cohesión por la colaboración de los ligamentos, según la actividad propia de cada miembro, para el crecimiento y edificación en el amor" $(\mathrm{Ef} 4,16)$. Así mismo, puesto que es una realidad que se realiza en la historia, es en la historia en la que conocemos su ser, al menos su proceso hasta ahora, porque lo que ella es en su plenitud todavía falta para que la conozcamos. Según Pablo, ella es un movimiento puesto en marcha por Dios y orientado por su Espíritu. Fue, precisamente, la hipótesis del desarrollo la que capacitó a Newman para mirar a la Iglesia católica como la continuación de la Iglesia de los Padres (Newman, 2003).

Ella es incomprensible si no se conocen sus tensiones internas, sus luchas, sus conflictos, sus divisiones, errores y pecados. Incluso sus enemigos, por lo que podemos decir con Pascal y Lubac que "ella, como Cristo, debe estar en agonía hasta el fin del mundo" (Lubac, 1968, 247). Pero también es necesario tener en cuenta la obra salvadora que el Seńor realiza en ella y con ella. Por ejemplo, es necesario tener en cuenta la división con la Iglesia ortodoxa oriental o con el protestantismo, así como es necesario tener en cuenta las herejías. Ahí se conoce lo profundamente humana que es, pero también el arcano misterio de salvación que actúa en ella. "En verdad, en la Iglesia, más que en Cristo, todo es contraste y paradoja" (Lubac, 1968, 34) dice Lubac.

Ella no es solo el signo más manifiesto de la obra salvadora del Señor en la historia, ella es también el signo más claro de la presencia del Misterio de Dios en esa historia. ¡Qué paradoja tan desconcertante es la Iglesia! A menudo aparece débil ante el mundo, mientras que muchos la ven fuerte y orgullosa. Y, sin embargo, Dios está siempre actuando en ella. La razón de su ser paradójico es que es profundamente humana, pero también es un misterio divino, "una realidad compleja que está integrada de un elemento humano y otro divino" (Concilio Vaticano II, L. G. n. 8). En ella podemos experimentar y cantar las 
maravillosas obras de Dios, pero también podemos sufrir "el misterio de la iniquidad", la maldad e insensatez humana. Como esposa del Señor, la Iglesia ha sido a veces una esposa infiel, como lo fue Israel. Así lo confiesa Lubac: "Esta esposa de Cristo, que su Esposo ha querido perfecta, santa, inmaculada, no es tal más que en su principio" (Lubac, 1968, 240). ¿Dónde mejor que en la Iglesia podemos conocer lo que es el pecado, pero al mismo tiempo el Misterio de salvación y el amor y la gracia de Dios? En la Iglesia sentimos terror y gozo, porque en ella confluyen y se encuentran los misterios de Jesucristo y del ser humano. Su propia historia demuestra el inmenso amor que el Señor le tiene.

No es que el Misterio de Cristo y la obra de la salvación se reduzcan o se limiten a la Iglesia, pero sin la Iglesia es imposible tener una comprensión completa de ese misterio. Al igual que los hongos brotan por doquiera en la tierra gracias al viento y al agua, así mismo la Iglesia brota por doquiera en la misma tierra gracias al soplo del Espíritu. Así empezó a brotar en congregaciones locales difundidas por toda la tierra, como un nuevo pueblo o una nueva raza de seres humanos. Pero mientras que el primer fenómeno es natural y tiene una explicación científica, la Iglesia es un fenómeno sobrenatural que solo la fe puede explicar. Ella es un objeto de fe. Esto es así porque el sobrenatural histórico es el humus de la Iglesia. Pablo dice que ella es un cultivo que él mismo plantó y que Apolo regó, pero al cual es Dios quien da el crecimiento (1, Cor 3,6-9). Esto significa que la iglesia es una singularidad sobrenatural en la historia humana. Es la gran obra de Dios en la historia, por lo que para contemplar la acción de Dios en este mundo es necesario mirar a la Iglesia, porque es allí donde Dios actúa de modo más admirable y evidente. En ella habita, de manera especial, el Misterio de Dios y su plan de salvación. El Misterio de Dios es el abismo insondable de la Santa Trinidad. Y es allí donde se arraiga el ser recóndito de la Iglesia, puesto que ella está dentro del plan secreto de salvación: "la vida de la Iglesia está escondida con Cristo en Dios hasta que aparezca con su Esposo en la gloria" (L. G. n. 6). Por eso, el "supremo principio de su misterio" es la Santa Trinidad (U. R. n. 2). O en palabras de Lubac, "la Iglesia es una misteriosa extensión de la Trinidad en el tiempo" (Lubac, 1967, 48). En la Iglesia resplandece de manera particular, no exclusiva, la obra salvífica de Dios, y es por esto que ella es también constitutivamente una realidad humana y, por esto mismo, una realidad en la que se percibe el pecado.

¿Cuál es el misterio del que brota la Iglesia y en el cual ella se arraiga? Repitámoslo: es el misterio de Jesucristo que se prolonga en la historia, y es el misterio de salvación que él realiza en la historia: "el misterio o plan secreto que Dios realiza en Cristo". El Misterio oculto de la historia es el Reino de Dios, su fuerza es la que da vida a la Iglesia y la sustenta, pero también es la que determina a la historia humana: "Cuando la Iglesia de la tierra llegue a su estado definitivo, se dará el Reino de los cielos. Entonces ella llegará a ser lo que es. Porque ella es ese reino en germen. Ella lo es en sustancia... Constituye su inauguración. Asegura su presencia actual y actuante en medio de nosotros" (Lubac, 1968, 48). La salvación no está en el otro-mundo sino en el Reino de Dios que ya está sembrado en este mundo y el cual la Iglesia tiene la tarea de cultivar.

Lo más definitivo para el hombre no son los misterios del más-allá, los del otro lado espacial, tampoco los misterios cosmológicos que pertenecen a la ciencia, sino los misterios de la historia. Más aún, lo definitivo es el misterio de Jesucristo. Por eso Pablo afirma: que en Cristo "están ocultos todos los tesoros de la sabiduría y de la ciencia” ( $\mathrm{Col} \mathrm{2,} \mathrm{2-3).}$ 
Tenemos, entonces, que el ser de la Iglesia es dinámico-escatológico y encarnacionista. Ella no está ligada a ninguna época y se encarna en todas, tampoco lo está a ninguna nación o continente, ni a ninguna cultura, aunque ha alentado el nacimiento de muchas y está a la base de gran número de culturas y de países. Pero la Iglesia peregrina hacia su plenitud. Ella debe ir por todo el mundo difundiendo la semilla evangélica del Reino salvador. Para entenderla es necesario saber cómo nació y cómo ha ido realizando su ser en la historia, vivificada por el Espíritu y animada por el esjaton, que nace del mismo Espíritu. Entender cómo en ella brotan, a menudo, personajes carismáticos, "hombres y mujeres de los que no era digno el mundo" (Heb 11,38), y cómo se producen en ella pensamientos teológicos que la iluminan y la impulsan: Pablo y su evangelio del Cristo que vive hoy, Orígenes y los Padres griegos, san Agustín y los Padres latinos, la vida y el pensamiento monacal, los papas Gregorio VII e Inocencio III, Francisco y Domingo y el pensamiento teológico franciscano y tomista, la escuela de Salamanca y la escolástica barroca, Teresa de Ávila y Juan de la Cruz, Ignacio de Loyola, la obra y el pensamiento jesuítico, incluido aquel " ad mentem suarezii", la espiritualidad francesa; la neoescolástica y el Vaticano I, y luego la corriente teológica que viene desde Newman y se reavivó con la Nouvelle théologie y dio su fruto en el Vaticano II, la inmensa obra de la evangelización de América y las conferencias episcopales de este continente. Cada uno de estos movimientos ha contribuido a la realización del ser eclesial y le han dado orientación y guía en las distintas épocas en las que ella ha debido encarnarse para cumplir con su tarea de anunciar el Evangelio del Reino y difundir la obra salvadora del Señor.

Un día, el Señor preguntó a sus discípulos: “¿quién dice la gente que soy yo?... ¿Y vosotros, quién decís que soy yo?” (Mc 8, 27b.29a). Esta es la pregunta fundamental que todo cristiano debe hacerse. Luego viene otra pregunta: y tú, ¿quién o qué dices que es la Iglesia? No hay duda de que ella es una realidad muy inquietante que despierta muchas preguntas. ¿Por qué y para qué existe ella? ¿Existe para satisfacer las necesidades religiosas de la gente? ¿O para contribuir al progreso de la sociedad humana? Si es para esto último, ¿en qué consiste ese progreso y de qué manera puede ella contribuir a él? Si no fue creada por el Jesús histórico, ¿quién la creó, cómo, cuándo y para qué? ¿Para continuar la obra de Jesús? ¿Cuál es esa obra? ¿Qué posee la Iglesia para realizar su función en el mundo, una función que no es religiosa ni tampoco de simple desarrollo o progreso humano? Si ella está al servicio de la obra salvadora de Cristo, ¿qué es y cómo se realiza esa obra salvadora? Si está al servicio del Reino de Dios, ¿qué fue lo que anunció Jesús, qué es el Reino de Dios y cómo se distingue él de ella? ¿Qué posee la Iglesia? De manera inmediata podemos responder: ella es la portadora de varios tesoros: el Misterio de Jesucristo, lo cual implica el Misterio de la Cruz y de la Pascua; el Misterio del Reino, la adoración de Dios en la liturgia; el Evangelio y su tarea de evangelizadora; el dinamismo salvador escatológico. Así mismo, la Iglesia tiene todo un sistema de pensamiento, un sistema de valores y unas instituciones sumamente sólidas. Sin embargo, en último término, la Iglesia no se fundamenta en ideas o en valores éticos, ni tampoco en instituciones muy sólidas, sino en un Misterio del cual brotan instituciones, ideas y valores.

\section{Referencias}

Barsotti, D. (1967). El apocalipsis. Una respuesta al tiempo. España, Madrid: Sígueme.

Boersma, H. (2012). Nouvelle Théologie and Sacramental Ontology. A Return to Mystery. Oxford: Oxford University Press. 
Buber, M. (1960). The Prophetic Faith. New York: Harper \& Row.

Connor, S. (ed). (2004). The Cambridge Companion To Postmodernism. Cambridge: Cambridge University Press

Daniélou, J. (1953). Essai sur le mystère de l’histoire. París: Seuil.

De Lubac, H. (1967). Paradoxe et Mystère de l'Eglise. París: Aubier.

De Lubac, H., (1968). Méditation sur l'Eglise. París: Aubier.

Dulles A., S.J. (1975). Modelos de la Iglesia. Estudio critico sobre la Iglesia en todos sus aspectos. Bogotá: Sal Terrae.

Dunn, J., \& Martínez, S. F. (2013). El cristianismo en sus comienzos: Comenzando desde Jerusalén. Navarra: Editorial Verbo Divino.

Gillman, N. (2000). Contemporary Jewish Theology. The Blackwell Companion to Judaism. Oxford: Blackwell, $441-60$.

Eliade, M. (2009). El mito del eterno retorno. Madrid: Alianza.

Flynn G., Murray P.D. (2013). Ressourcement. A Movement for Renewal in Twentieth-Century Catholic Theology. Oxford: Oxford University Press.

Fackenheim, E.L. (2002). La Presencia de Dios en la historia. Madrid: Sígueme.

Ford, David F., (ed). (2005). The Modern Theologians. An Introduction to Christian Theology since 1918. New Jersey: Blackwell Publishing.

Galeano, A. (2010). Visión Cristiana de la Historia. Ensayo de Escatología. Bogotá: San Pablo.

Galeano, A. (2011). Idea Cristiana del Hombre y la Ciberantropología. Ensayo de antropología latinoamericana. Bogotá: San Pablo.

Galeano, A. (2017). Una eclesiología histórica-escatológica para la postmodernidad. El cambio de paradigma dentro de la orientación postmoderna hacia la historia y la hermenéutica. Cuestiones Teológicas, 44 (102), 397-421.

Haight, R. (2004). Christian community in history (Vol. 1). Londres: A\&C Black.

Heschel, A.J. (1982). Man is not alone: A Philosophy of Religion. Portland: Farrar, Straus \& Giroux.

Heschel, A.J. (1973). Los profetas II. Concepciones históricas y teológicas. Buenos Aires: Paidós.

Kevin J. Vanhoozer (ed). (2003). The cambridge companion to postmodern theology. Cambridge: Cambridge University Press.

Lindbeck, G. A. (2003). The church in a postliberal age. Cambridge: Wm. B. Eerdmans Publishing.

Mead, W.R. (2008). God and Gold: Britain, America and the Making of the Modern World. Nueva York: Vintage.

Metz, J.B. (1972). Antropocentrismo cristiano. Sobre la forma de pensamiento de Tomás de Aquino. Madrid: Sígueme.

Moltmann, J. (1974). Conversión al futuro. Madrid, Barcelona: Marova-Fontanella.

Pablo VI. (1986). Exhortación Apostólica: el Anuncio del Evangelio hoy. Bogotá: Paulina.

Ratzinger, J. (1971). The Theology of History in St Bonaventure. Chicago: Franciscan Herald Press.

Richard, L. (1966). El Misterio de la Redención. Madrid: Península. 


\section{El sobrenatural histórico y la Iglesia}

San Agustín. (1964). Enarraciones sobre los Salmos. Tomos I al IV. Madrid: BAC.

Scott, P., \& Cavanaugh, W. T. (Eds.). (2004). The Blackwell companion to political theology. Oxford: Blackwell.

Sim, S. (2013). The Routledge companion to postmodernism. Londres, Nueva York: Routledge.

Vatican II, Documentos, BAC Madrid 1976, L.G.

Von Balthasar, H. (1955). La Théologie de l'Histoire. París: Plon.

Von Rad, G. (2009). Teología del Antiguo Testamento II. Las Tradiciones proféticas de Israel. Madrid: Sígueme.

Walls L. (ed.). (2010). The Oxford Handbook of Eschatology. Oxford: Oxford University Press.

Ward, G. (ed.). (2005). The Blackwell Companion to Postmodern Theology. New Jersey: Blackwell Publishing. 